\title{
Controls on the Prevalent Occurrence of Cretaceous Oil Sands
}

\author{
Dr. Timothy P Bata ${ }^{1 *}$, Ezekiel H Elijah ${ }^{2}$, John Jitong Shirputda ${ }^{3}$ and Titus Adinye ${ }^{\mathbf{1}}$ \\ ${ }^{1}$ Associate Professor of Petroleum Geology, Abubakar Tafawa Balewa University, Nigeria \\ ${ }^{2}$ National Productivity Center Bauchi, Nigeria \\ ${ }^{3}$ National Centre for Petroleum Research and Development, ATBU, Nigeria
}

Received: 阱 April 11, 2018; Published: 制April 25, 2018

*Corresponding author: Timothy P Bata, Associate Professor of Petroleum Geology, Abubakar Tafawa Balewa University, Bauchi, Nigeria

\begin{abstract}
The widespread occurrence of Cretaceous oil sands can be attributed to various geological processes, most of which can be linked to the warm climatic conditions that prevailed globally at that time. The extreme global warmth witnessed during the Cetaceous caused a rise in global sea level, which resulted in flooding of most continental margins, depositing transgressive sands at shallow depths directly on the Precambrian basement, or much older sedimentary strata. Another important geological factor that contributed to the widespread occurrence of the Cretaceous oil sands was the availability of viable petroleum source rocks that generated oils at the time of, or shortly after, the Cretaceous oil sands were deposited. Oils migrated into the shallow Cretaceous reservoir sands through the plane of unconformity underlying them. The warm climatic conditions witnessed in the Cretaceous also implied that the reservoir had conditions that were favourable for optimum microbial activities.
\end{abstract}

\section{Introduction}

Important geological factor controlling the widespread occurrence of these Cretaceous oil sands is the prevalence of Cretaceous reservoir sands with good reservoir capabilities. Deposition of these reservoir sands can be linked to the marine transgression that occurred during the Cretaceous period which was caused by the unique greenhouse climatic condition witnessed in the Cretaceous. This extreme global warmth was a direct consequence of the high level of atmospheric $\mathrm{CO}_{2}$ that prevailed globally at that time [1-3]. Variations in global climatic conditions are an important influence on variations in the global sea level. When global temperatures rise, the volume of seawater increases, as polar ice caps melt. Conversely, when global temperatures fall, polar ice caps grow and the volume of seawater decreases, causing the global sea level to fall. An increase in the rate of sea-floor spreading during the Cretaceous continental break-up also resulted in a decrease in the volume of ocean basins as hot rising magma caused the lithosphere to be lifted along the mid-ocean ridges, resulting in the reduction of the volume of the ocean basins. This combination of warm climatic conditions and sea-floor spreading resulted in a significant rise in the global sea level in the Cretaceous, causing flooding of most of the continental margins by the oceans $[3,4]$.
Another important geological factor that contributed to the widespread occurrence of the Cretaceous oil sands was the availability of viable petroleum source rocks that generated oils at the time of, or shortly after, the Cretaceous oil sands were deposited. The Cretaceous period is known to be closely associated with organic-rich sediments (petroleum source rocks) that were deposited during the various widespread Cretaceous anoxic events e.g: $[5,6]$. Oils generated from these organic-rich sediments (source rocks) could easily migrate into the Cretaceous transgressive sands through the underlying plane of unconformity. There is field evidence showing cases of hydrocarbon migration over hundreds of kilometres through the plane of unconformity underlying the Cretaceous transgressive sands. An example is the heavy oil occurring in the Athabasca oil sand which is believed to have been partly derived from shale source rocks several hundred kilometres away from the reservoir sand [7,8].

Temperature is known to have a significant effect on the activities of microbes that are capable of degrading oils e.g. $[3,9,10]$. The temperature range in a petroleum reservoir will determine what type of microorganisms can thrive in the reservoir, while the specific temperature within the range will affect the rate of 
microbial activities. Microorganisms are often classified according to their optimal temperature range. Psychrophilic microorganisms commonly thrive in environments with temperatures ranging between $0{ }^{\circ} \mathrm{C}$ and $20{ }^{\circ} \mathrm{C}$. Mesophilic microorganisms commonly thrive in environments with temperatures ranging between $20{ }^{\circ} \mathrm{C}$ and $40{ }^{\circ} \mathrm{C}$, while thermophilic microorganisms commonly thrive in environments with temperatures ranging between $40{ }^{\circ} \mathrm{C}$ and $80{ }^{\circ} \mathrm{C}[11] .80{ }^{\circ} \mathrm{C}$ is considered as the sterilization temperature for most microorganisms, beyond which only hyperthermophilic microorganisms can thrive e.g. [12].
Microorganisms, therefore, have an optimum temperature at which they are most efficient. The further from this temperature a petroleum reservoir strays, the less productive the microorganisms in it will be. An accepted rule of thumb is that the rate of biodegradation at least doubles for every $10{ }^{\circ} \mathrm{C}$ increase [11], (Figure 1). The optimum temperature for microbial activity is between $25^{\circ} \mathrm{C}$ and $30^{\circ} \mathrm{C} \mathrm{e.g.} \mathrm{[13],} \mathrm{which} \mathrm{is} \mathrm{in} \mathrm{fact} \mathrm{very} \mathrm{similar} \mathrm{to} \mathrm{the}$ estimated average global surface temperature of $28{ }^{\circ} \mathrm{C}$ witnessed during the Cretaceous [1,2].

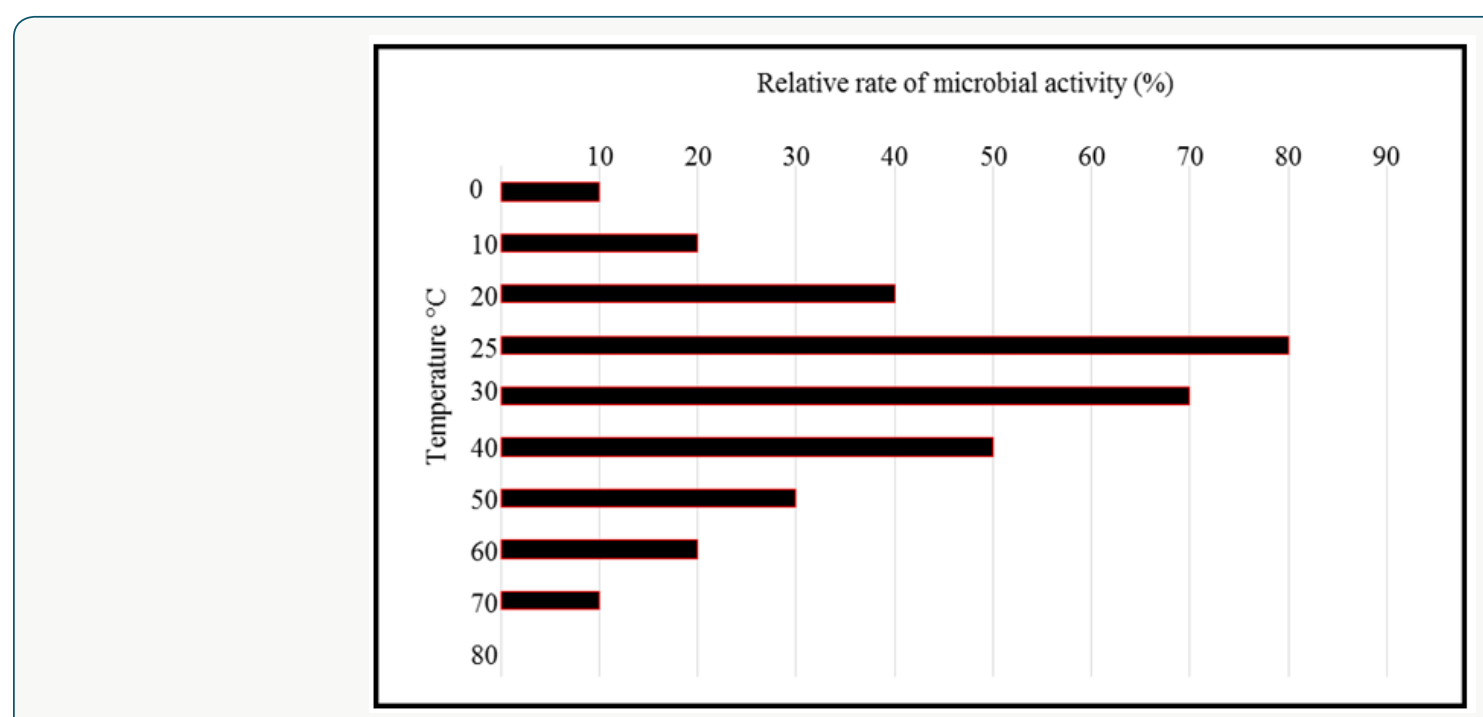

Figure 1: Chart showing variation in the relative rate of microbial activity with temperature. Note the optimum temperature for microbial activity is between $25^{\circ} \mathrm{C}$ and $30^{\circ} \mathrm{C}$ after which microbial activities decline down to the sterilization temperature at 80 ${ }^{\circ} \mathrm{C}$.

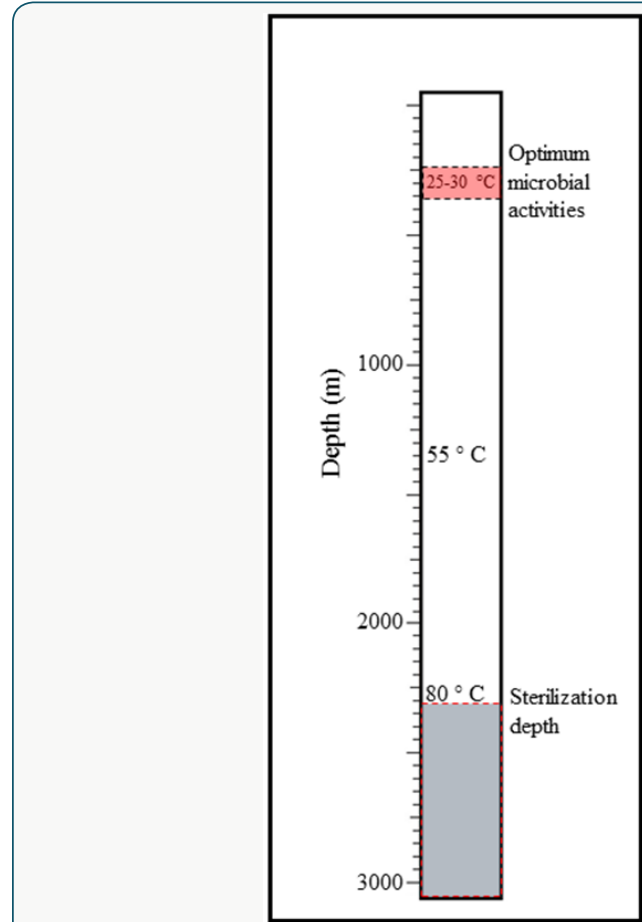

Figure 2: Effect of variation in temperature with depth on microbial activities. Note that optimum microbial activities occur at a depth of about $300 \mathrm{~m}$.
Measurements of microbial cell densities in aquifer systems carried out by [14] revealed a significant decrease in microbial cell densities with depth, suggesting relative increase in microbial activities at shallow depths similar to the depth of occurrence of most Cretaceous oil sands. Assuming a normal geothermal gradient of about $25^{\circ} \mathrm{C} / \mathrm{km}$ for the present day, optimum microbial activity will be expected to occur at a depth of about $300 \mathrm{~m}$, after which microbial activity begins to decline until it gets to the sterilization depth of about $2300 \mathrm{~m}$ where most microbial activities cease (Figure 2).

\section{References}

1 Skelton PW, Robert A Spicer, Simon P Kelley, Iain Gilmour (2003) The Cretaceous world. Cambridge University Press, London.

2 Wang Y, Huang C, Sun B, Quan C, Wu J, et al. (2014) Paleo- $\mathrm{CO}_{2}$ variation trends and the Cretaceous greenhouse climate. Earth-Science Reviews 129: 136-147.

3 Bata T (2016) Geochemical Consequences of Cretaceous Sea Level Rise. Unpublished PhD thesis submitted to the Department of Geology and Petroleum Geology, University of Aberdeen.

4 Coe MT, Costa MH, Botta AL, Birkett C (2002) Long-term simulations of discharge and floods in the Amazon Basin.

5 Erba E (2004) Calcareous nannofossils and Mesozoic oceanic anoxic events. Marine Micropaleontology 52(1-4): 85-106. 
6 Jenkyns HC (2010) Geochemistry of oceanic anoxic events. Geochemistry, Geophysics, Geosystems 11(3): 1-30.

7 Head IM, Jones DM, Larter SR (2003) Biological activity in the deep subsurface and the origin of heavy oil. Nature 426: 344-352.

8 Larter SR, Head IM, Bennett B, Huang H, Adams JJ, et al. (2013) The roles of water in subsurface petroleum biodegradation-Part 1 . The role of water radiolysis. Geo Convention 2013: Integration.

9 Peters KE, Walters CC, Moldowan JM (2005) The Biomarker Guide: Biomarkers and isotopes in petroleum exploration and Earth history, v. 2. Cambridge, Cambridge University Press, USA.

10Tripathi V, Abhilash PC, Singh HB, Singh N, Patra DD, (2015) Effect of temperature variation on lindane dissipation and microbial activity in soil. Ecological Engineering 79: 54-59.
11Dettmer K (2002) A discussion of the effects of thermal remediation treatments on microbial degradation processes. National Network of Environmental Management Studies Fellow. Washington DC, USA.

12Adams J, Steve L, Barry B, Haiping H, Joseph W, et al. (2013) The dynamic interplay of oil mixing, charge timing, and biodegradation in forming the Alberta oil sands: Insights from geologic modeling and biogeochemistry 64: 23-102.

13Pietikäinen J, Pettersson M, Bååth E (2005) Comparison of temperature effects on soil respiration and bacterial and fungal growth rates. FEMS Microbiology Ecology 52(1): 49-58.

14McMahon S, Parnell J (2014) Weighing the deep continental biosphere. FEMS microbiology ecology 87(1): 113-120. (c) This work is licensed under Creative

To Submit Your Article Click Here:

Submit Article

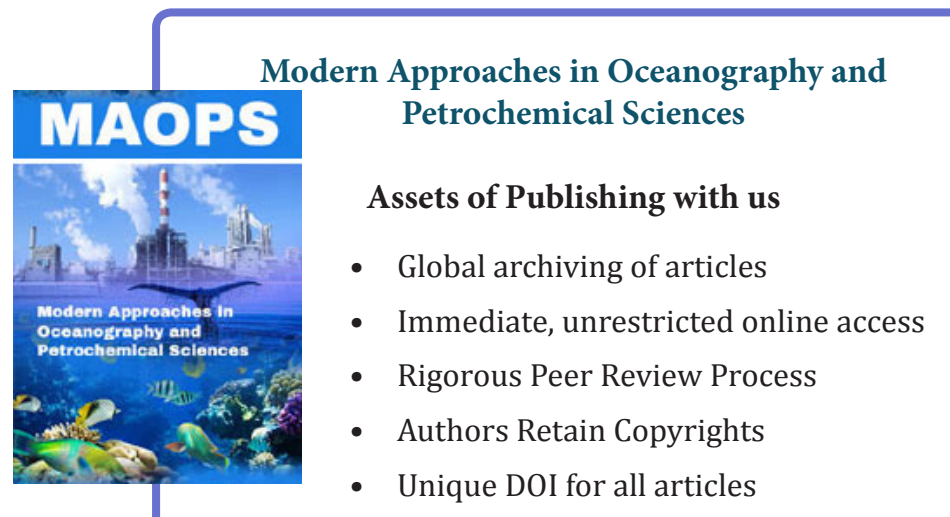

